\title{
Evaluation of Fenton's Reagent Toxicity to Biomphalaria Alexandrina Snails
}

\section{Abdel Wareth MTA*}

Department of Environmental Research and Medical Malacology, Theodor Bilharz Research Institute, Egypt

*Corresponding author: Marwa TA Abdel-Wareth, Department of Environmental Research and Medical Malacology, Theodor Bilharz Research Institute, Egypt, Email: marwatamim2001@ hotmail.com

\section{Research Article}

Volume 3 Issue 1

Received Date: January 30, 2020

Published Date: February 19, 2020

DOI: $10.23880 /$ izab-16000206

\section{Abstract}

Fenton's reagent is considered a promising disinfecting agent as it has antimicrobial activity. In the present study, effective antifungal Fenton concentrations were investigated on Biomphalaria alexandrina snails as bio indicators of toxicity. Generally, they resulted in low mortality rate of snails, as only $20 \%$ mortality was recorded after $60 \mathrm{~min}$ of exposure. Also the activities of two antioxidant enzymes; catalase (CAT) and superoxide dismutase (SOD) in snails' tissues were investigated at different time intervals. Although the activities of both enzymes were different from control group, there was not a pronounced enhancement or inhibition. In conclusion, certain Fenton concentrations can be used as inexpensive and environmentallyfriendly disinfecting agents as they are safe on snails which are good bioindicators of toxicity.

Keywords: Biomphalaria alexandrina; Fenton's Reagent; Catalase; Superoxide Dismutase

Abbreviations: SOD: Superoxide Dismutase; ROS: Reactive Oxygen Species; CAT: Catalase; LSD: Least Significant Difference.

\section{Introduction}

Different water treatment technologies have been applied to kill bacteria and fungal spores. Chlorine, monochloramine, ozone and chlorine dioxide are amongst the chemical disinfectants which were previously investigated [1,2]. The interest in environmentally friendly, non-toxic, inexpensive and degradable oxidizing agent directed researchers to hydrogen peroxide (H2O2); it is increasingly used in a number of medical and industrial applications, and also in environmental ones such as water treatment [3]. Hydrogen peroxide is characterized by its broad spectrum activity, which includes efficacy against bacterial endospores, mold spores and viruses, besides lack of environmental toxicity due to its complete degradation [4]. The addition of ferrous salts to aqueous hydrogen peroxide (known as the Fenton reaction) may increase the levels of reactive oxygen species (ROS) by accelerating the decomposition of hydrogen peroxide and generating highly reactive intermediate species, including ferric iron $(\mathrm{Fe} 3+)$, hydroperoxyl radicals $\left(\bullet \mathrm{O}_{2} \mathrm{H}\right)[5]$ and/or superoxide radicals $\left(\bullet \mathrm{O}_{2}^{-}\right)$[6]. Thus, the kinetics and the overall antimicrobial effect of hydrogen peroxide are increased, especially at lower concentrations. The antimicrobial effect of Fenton reaction had been investigated for inactivation of junin virus, Escherichia coli, and spores of Bacillus subtilis [7-9]. Moreover, Penicillium chrysogenum, Stachybotrys charatum, Aspergillus versicolor and Cladosporium cladosporioides spores were adversely 
affected by exposure to Fenton's reagent [10]. Recently, Abdel-Wareth and Abdel-Wahed [11] have reported that certain Fenton concentrations resulted in a noticeable inactivation of the spores of Aspergillus niger and Penicillium citrinum.

Invertebrates have been used for ecotoxicological studies due to their importance in trophic chains and their sensitivity to chemical pollution [12]. Gastropods, which are the most abundant mollusks, have been successfully used as bioindicators of toxicity by different compounds, e.g. metals and pesticides [13-17].

Biomphalaria alexandrina snails have been extensively studied because of their role as intermediate hosts for Schistosoma mansoni. Many researchers considered these snails as good models for laboratory monitoring of environmental toxicity [18-21]. These snails are characterized by their availability, easy collection, the ability to grow under laboratory conditions, also they need little space and small quantities of test samples which require evaluation, this eventually reduces the whole cost of the experiment. The aim of this study is to evaluate the suitability of B. alexandrina snails as bioindicators of Fenton toxicity. This is achieved through determining the percentage of snails' mortality, and the alteration of catalase and superoxide dismutase enzymes levels in snails tissues. These enzymes were chosen because they represent the first line of defence against the effect of reactive oxygen species.

\section{Materials and Methods}

\section{Exposure of Biomphalaria Alexandrina Snails to the Most Effective Fenton Concentrations}

Adult Biomphalaria alexandrina snails $(8-10 \mathrm{~mm}$ in diameter) were exposed in triplicates to four Fenton concentrations $\left(2 \% \mathrm{H}_{2} \mathrm{O}_{2}+0.025 \mathrm{~g} \quad \mathrm{FeSO}_{4} / 100 \mathrm{ml}\right.$, $3 \% \mathrm{H} 2 \mathrm{O} 2+0.025 \mathrm{~g} \mathrm{FeSO}_{4} / 100 \mathrm{ml}, 3 \% \mathrm{H}_{2} \mathrm{O}_{2}+0.075 \mathrm{~g}$ $\mathrm{FeSO}_{4} / 100 \mathrm{ml}$ and $3 \% \mathrm{H}_{2} \mathrm{O}_{2}+0.1 \mathrm{~g} \mathrm{FeSo}_{4} / 100 \mathrm{ml}$ ). These concentrations were chosen on the basis of their activity against Aspergillus niger and Penicillium citrinum spores in a previous study carried out by the same author [22]. 30 snails were exposed to each concentration; 10 snails per one Liter of the treatment. Recovery took place after 0 , 30, 60 and 90 minutes of exposure by transferring snails to clean deionized water. A control group was maintained under the same circumstances. The snails in each treatment were allowed to thrive for $24 \mathrm{hr}$, then they were crushed between two slides, shell remains were removed, then the soft parts of the snails were withdrawn, weighted and put in labeled eppindorf tubes for enzyme assay.

\section{Enzyme Assay}

Snails soft tissues were washed in distilled $\mathrm{H} 2 \mathrm{O}$, followed by cold phosphate buffer ( $\mathrm{pH}$ 7.4), and then re suspended in the same buffer. The cell suspension was disrupted by homogenization at $20000 \mathrm{rpm}$. The temperature during homogenization was maintained at $4-6^{\circ} \mathrm{C}$ by chilling in an ice-salt bath. Filtration of samples was carried out prior to its cold centrifugation at $13000 \mathrm{~g}$ for $20 \mathrm{~min}$. The activities of superoxide dismutase (SOD) and catalase (CAT) were measured in the extracts according to Nishikimi, et al. [23], Fossati, et al. [24] and Aebi [25], respectively.

\section{Statistical Analysis}

The significance of difference between the values of enzyme activities at different time intervals, and between different treatments at the same time was determined by ANOVA using SPSS, where the post hoc test was least significant difference (LSD) (version 17.0).

\section{Results}

Biomphalaria alexandrina snails were selected as bioindicators of the side effects of antifungal Fenton concentrations. The mortality of snails is shown in Figure 1 , the snails exposed to the lowest Fenton concentration showed no mortality after $30 \mathrm{~min}$. after $60 \mathrm{~min}$ of exposure, only $20 \%$ of the snails died in each of $3 \% \mathrm{H}_{2} \mathrm{O}_{2}$ combined with 0.025 and $0.075 \mathrm{~g} \mathrm{Fe}^{2+}$. On the other hand, $3 \% \mathrm{H}_{2} \mathrm{O}_{2}$ catalyzed by the highest $\mathrm{Fe}^{2+}$ concentration $\left(0.1 \mathrm{~g} \mathrm{Fe}^{2+}\right)$ resulted in $40 \%$ death of snails after $60 \mathrm{~min}$.

Concerning the antioxidant enzymes of snails, it was found that despite the fluctuations in CAT activities, there were no significant differences $(P>0.05)$ as the time extended to $60 \mathrm{~min}$ in case of exposure to the lowest Fenton concentration. Also, the values of CAT concentrations were very close in case of $3 \% \mathrm{H} 2 \mathrm{O} 2$ catalyzed by $0.025 \mathrm{~g} \mathrm{Fe}^{2+}$ at 0 and $60 \mathrm{~min}$, and at 30 and $90 \mathrm{~min}$. Moreover, the values of CAT activity were nearly the same after 60 and $90 \mathrm{~min}$ of exposure to $3 \% \mathrm{H}_{2} \mathrm{O}_{2}$ catalyzed by $0.075 \mathrm{~g} \mathrm{Fe}^{2+}$. Similarly, there was no significant difference $(\mathrm{P}>0.05)$ in CAT activity after 0 and $90 \mathrm{~min}$ of exposure to the highest Fenton concentration (Figure 2). Contradictory, the fluctuations of SOD were more pronounced, it was observed that the maximum elevation of SOD was after $60 \mathrm{~min}$ of exposure to the highest Fenton concentration, followed by $3 \% \mathrm{H}_{2} \mathrm{O}_{2}$ catalyzed by $0.025 \mathrm{~g} \mathrm{Fe}^{2+}$ after 90 min (Figure 3). 


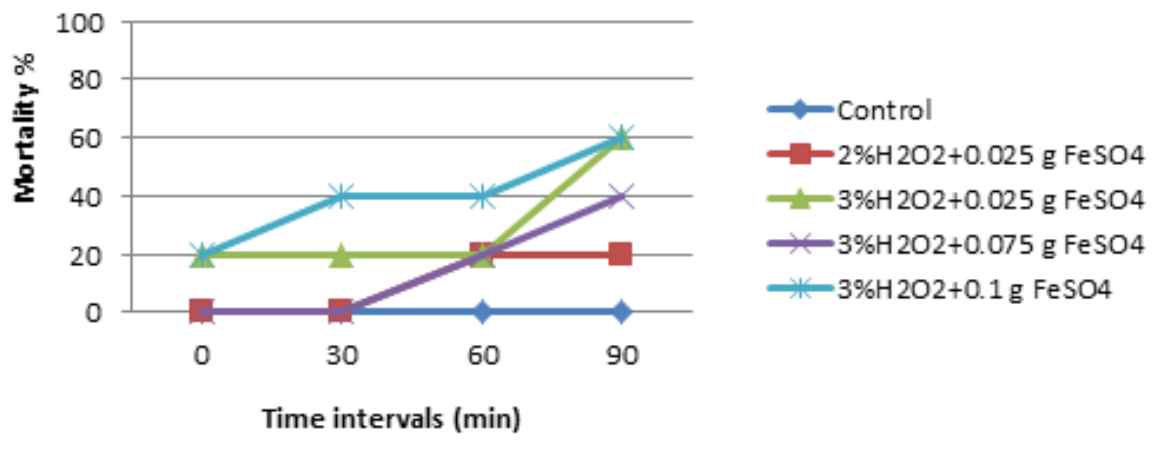

Figure 1: Mortality percentage of Biomphalaria alexandrina snails treated with the effective Fenton concentrations at different time intervals.

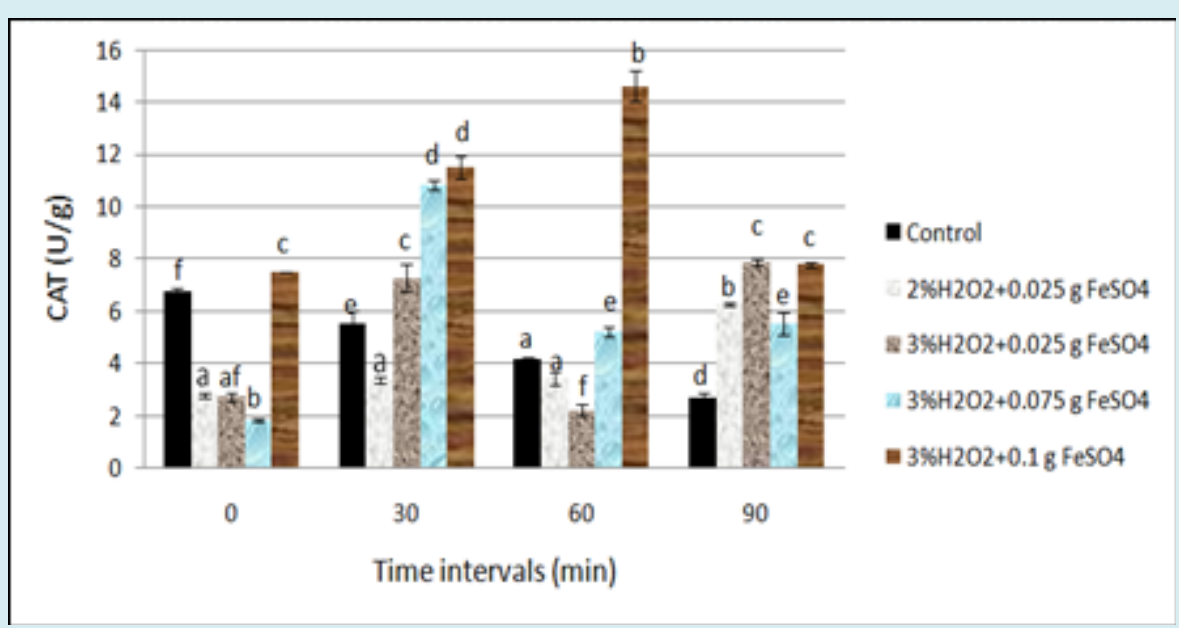

Figure 2: Mean values of catalase in tissues of Biomphalaria alexandrina snails treated with the effective Fenton concentrations. Different letters indicate significance $(\mathrm{P}<0.05)$.

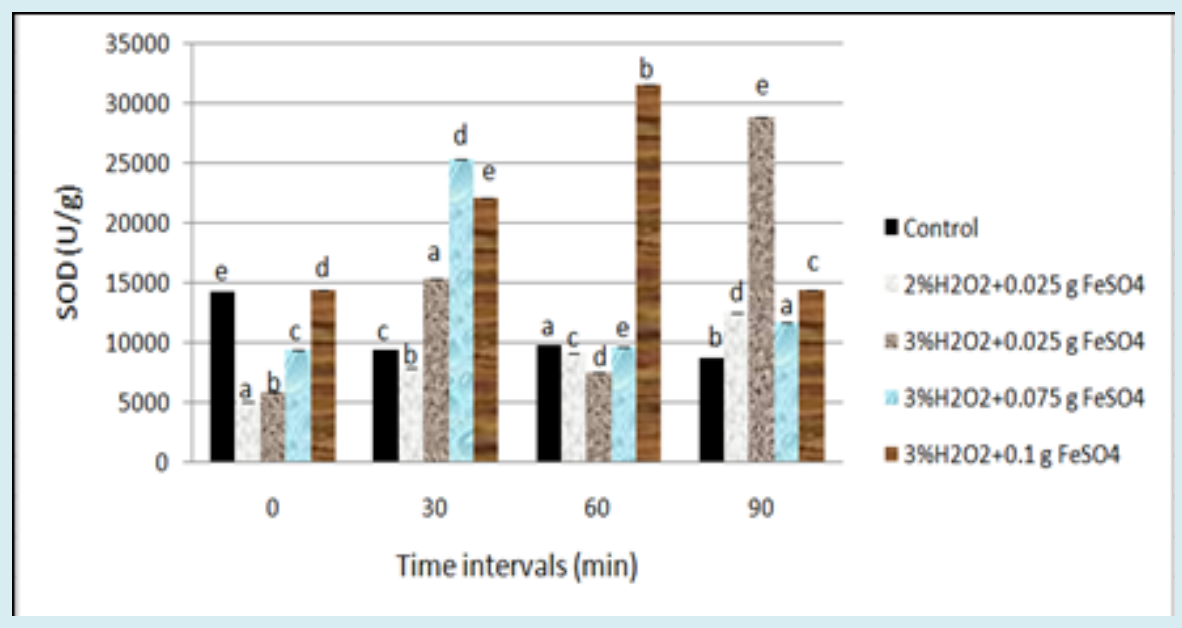

Figure 3: Mean values of superoxide dismutase in tissues of Biomphalaria alexandrina snails treated with the effective Fenton concentrations. Different letters indicate significance $(\mathrm{P}<0.05)$. 


\section{Discussion}

Freshwater snails have been used as bio monitors of environmental pollution [26]. In the current work, Biomphalaria alexandrina snails exposed to the effective Fenton concentrations previously reported by Abdel-Wareth, et al. [22] showed low mortality percentages. This is in agreement with Fahmy, et al. [27]. They investigated the toxic effect of the oxidative stress on Biomphalaria alexandrina snails, where low mortality of snails was detected after their exposure to different concentrations of zinc oxide nanoparticles.

Concerning the antioxidant enzymes of snails in our study, it was noticed that exposure of snails to different Fenton concentrations for $90 \mathrm{~min}$ has no pronounced effect on CAT activity. Contradictory, there were fluctuations in SOD activity. CAT and SOD are considered the first line of defense against the effects of reactive oxygen species (ROS), and they have evolved in different tissues of vertebrates and invertebrates [28]. The enhanced SOD activity observed in the present study at certain concentrations was probably an adaptive mechanism by the snails to counteract the oxidative stress [29]. Fahmy, et al. [27] evaluated the effect of zinc oxide nanoparticles on SOD and CAT enzymes of B. alexandrina snails, as it was found that the oxidative stress is one of the most commonly reported mechanisms of nanoparticles toxicity [30]. They reported a decrease in both enzymes in the low concentration, while at the higher concentration of the compound, the activity of both enzymes significantly exceeded that of the control. Moreover, the increase of catalase activity observed in the current study after 30 and 90 min of exposure matches the findings of Sayed and Abdel-Wareth [31], as they reported similar induction of CAT after exposure of $B$. alexandrina snails to Huwa-san which is hydrogen peroxide combined with ionic silver.

\section{Conclusion}

The present results showed that the effective antifungal Fenton concentrations resulted in $20 \%$ mortality of Biomphalaria alexandrina snails after $60 \mathrm{~min}$ of exposure. Moreover, the tested Fenton concentrations noticeably alter the activity of SOD, while their effect on CAT was not significant. This indicates that $B$. alexandrina snails are suitable indicators of Fenton reagent toxicity.

\section{References}

1. Margolin AB (1997) Manual of environmental microbiology. American Society for Microbiology: Washington. Control of microorganisms in source water and drinking water. In: Hurst CJ, Knudsen GR, Mc Inerney MJ, Stetzenbach LD, Walter MV, et al. (Eds.), pp: 195-202.
2. Baker KH, Hegarty JP, Redmond BB, Reed NA, Herson DS (2002) Effect of oxidizing disinfectants (chlorine, monochloramine, and ozone) on Helicobacter pylori. Appl Environ Microbiol 68(2): 981-984.

3. Barrington D, Ghadouani A, Ivey G (2011) Environmental factors and the application of hydrogen peroxide for the removal of toxic cyanobacteria from waste stabilization ponds. J Environ Eng pp: 952-960.

4. Block SS (2000) Disinfection, Sterilization, and Preservation. $5^{\text {th }}$ (Edn.), Lea \& Febiger, Philadelphia, pp: 185-204.

5. Walling C (1975) Fenton's reagent revisited. Acc Chem Res 8: 125-131.

6. Smith BA, Watts RJ, Atkinson DA (2002) Destruction of DNAPLs by modified Fenton's Reagent. In Platform Abstracts of the Third International Conference on Remediation of Chlorinated and Recalcitrant Compounds; Monterey, California.

7. Sagripanti JL (1992) Metal-based formulations with high microbicidal activity. Appl Environ Microbiol 58(9): 3157-3162.

8. Sagripanti JL, Routson LB, Lytle CD (1993) Virus inactivation by copper or iron ions alone and in the presence of peroxide. Appl Environ Microbiol 59(12): 4374-4376.

9. Selvakumar A, Tuccillo ME, Muthukrishnan S, Ray AB (2009) Use of Fenton's reagent as a disinfectant. Remed 19(2): 135-142.

10. Yaari G, Tachiev G, Dean TR, Betancourt D, Long S (2007) Destruction of Aspergillus versicolor, Penicillium chrysogenum, Stachybotrys chartarum, and Cladosporium cladosporioides spores using chemical oxidation treatment process. Remed 17(2): 109-126.

11. Achiorno CL, Villalobos C, De Ferrari L (2010) Validation test with embryonic and larval stages of Chordodes nobilii (Gordiida, Nematomorpha): sensitivity to three reference toxicants. Chem 81(2): 133-140.

12. Oliveira Filho EC, Geraldino BR, Grisolia CK, Paumgartten FJR (2005) Acute toxicity of endosulfan, nonylphenolethoxylate, and ethanol to different life stages of the freshwater snail Biomphalaria tenagophila (Orbigny,1835). Bull Environ Contam Toxicol 75: 11851190.

13. Matthiessen $P$ (2008) An assessment of endocrine disruption in mollusks and the potential for developing internationally standardized mollusk life cycle test 
guidelines. Integr Environ Assess. Manage 4(3): 274284.

14. Ansaldo M, Nahabedian DE, Di Fonzo C, Wider EA (2009) Effect of cadmium, lead and arsenic on the oviposition, hatching and embryonic survival of Biomphalaria glabrata. Sci Total Environ 407(6): 1923-1928.

15. Giusti A, Leprince P, Mazzucchelli G, Thomé J, Lagadic $\mathrm{L}$, et al. (2013) Proteomic analysis of the reproductive organs of the hermaphroditic gastropod Lymnaea stagnalis exposed to different endocrine disrupting chemicals. PLoSOne 8(11): e81086.

16. Zounkova R, Jalova V, Janisova M, Ocelka T, Jurcikova J, et al. (2014) In situ effects of urban river pollution on the mud snail Potamopyrgus antipodarum as part of an integrated assessment. Aquat Toxicol 150: 83-92.

17. Verrengia Guerrero NR, Mozzarelli MN, Giancarlo $H$, Nahabedian D, Wider E (1997) Biomphalaria glabrata: relevance of albino organisms as useful tool for environmental lead monitoring. Bull Environ Contam Toxicol 59(5): 822-827.

18. Abd Allah AT, Thompson SN, Borchardt DB, Wanas MQA (1999) Biomphalaria glabrata: a laboratory model illustrating the potential of pulmonate gastropods as freshwater bio monitoring of heavy metal pollutants. Malacol 41(2): 345-353.

19. Cochón AC, Della Penna AB, Kristoff G, Piol MN, San Martín deViale LC, et al. (2007) Differential effects of paraquat on oxidative stress parameters and polyamine levels in two freshwater invertebrates. Ecotoxicol Environ Saf 68(2): 286-292.

20. Kristoff G, Verrengia Guerrero NR, Cochón AC (2010) Inhibition of cholinesterase and carboxylesterases of two invertebrate's species, Biomphalaria glabrata and Lumbriculus variegates by carbamate pesticide carbaryl. Toxicol 96(2): 115-123.

21. Abdel Wareth MTA, Abdel Wahed RT (2018) Response of Aspergillus flavus, Aspergillus niger and Penicillium citrinum to oxidative stress induced by Fenton's reagent. Int J Environ Stud 75(4): 605-622.

22. Nishikimi M, Rao NA, Yogi K (1972) Colorimetric determination of superoxide dismutase in tissues. Biochem Biophys Res Commun 46: 849-454.

23. Fossati P, Prencipe L, Berti G (1980) Use of 3, 5-dichloro-2 hydroxybenzenesulfonic acid/4-aminophenazone chromogenic system in direct enzymatic assay of uric acid in serum and urine. Clin Chem 26(2): 227-231.

24. Aebi H (1984) Catalase in vitro. Methods Enzymol 105: 121-126.

25. Jagtap JT, Shejule KB, Jaiswal DP (2011) Acute toxicity study of tributyltin chloride on the freshwater bivalve, Lamellidens marginalis. World J Fish Mar Sci 3(2): 100103.

26. Fahmy SR, Abdel Ghaffar F, Bakry FA, Sayed DA (2014) Ecotoxicological effect of sublethal exposure to zinc oxide nanoparticles on freshwater snail Biomphalaria alexandrina. Arch Environ Contam Toxicol 67(2): 192202.

27. Abdollahi M, Ranjabar A, Shadnia S, Nikfar S, Rezaie A (2004) Pesticide and oxidative stress. Med Sci Monit 10(6): 141-147.

28. Basopo N, Mumbamarwo LT, Mnkandla D, Naik YS (2014) Pollutant mixtures as stressors of selected enzyme activities of the aquatic snail Helisoma duryi. J Environ Chem Ecotoxicol 6(4): 27-37.

29. Mocan T, Clichici S, Agoston-Coldea L, Mocan L, Simon S, et al. (2010) Implications of oxidative stress mechanisms in toxicity of nanoparticles (review). Acta Physiol Hung 97(3): 247-255.

30. Sayed SSM, Abdel Wareth MTA (2017) The comparative effect of chlorine and Huwa-san as disinfecting agents on Biomphalaria alexandrina snails and free larval stages of Schistosoma mansoni. Parasitol Res 116(10): 2627-2635. 